\title{
PENINGKATAN KEMAMPUAN GURU BAHASA DALAM MENYUSUN RPP DENGAN MENGGUNAKAN METODE SUPERVISI AKADEMIK DI SMP
}

\author{
Eddy Abdullah \\ Sekolah Menengah Pertama Negeri 3 Matan Hilir Selatan \\ Email: eddyabdullahsmpn3mhs@gmail.com
}

\begin{abstract}
Abstrak
This study aims to improve the ability of language teachers in creating lesson plans using academic supervision methods. Academic supervision is one of the principals' tasks in developing teachers through the supervisory function to solve educational problems, including problems faced by teachers simultaneously and not looking for teacher errors. The form of this research is the School Action Research (SAR), which uses a qualitative approach with descriptive methods. In this study consists of two cycles and carried out using academic supervision methods to improve the ability in creating lesson plans in Indonesian and English subjects. The data obtained are in the form of teacher observation sheets in teaching supervision activities. From the results of analysts it was found that the ability to create lesson plans for language teachers increased from cycle I and cycle II, namely, cycle I to Indonesian language teachers I (60\%), Indonesian language teachers II (45\%), English language teachers I (50\%) and English teacher II (40\%) and in cycle II there was an increase in Indonesian language teacher I (80\%), Indonesian language teacher II (85\%), English teacher I (90\%) and English teacher II (75\%). The conclusion of this study is that academic supervision methods can improve the ability to create lesson plans in language teachers in Negeri 3 Matan Hilir Selatan.
\end{abstract}

\section{Keywords: Implementation, Academic Supervision Method, Teacher's Ability to Create Lesson Plans}

\section{PENDAHULUAN}

Perkembangan Ilmu Pengetahuan dan Teknologi (IPTEK) serta globalisasi komunikasi berdampak pada tuntutan pendidikan yang bermutu yang dapat mengikuti perkembangan IPTEK. Meningkatkan kualitas pendidikan adalah meningkatkan kualitas komponen- komponen sistem pendidikan diantaranya peserta didik, guru dan kepala sekolah. Salah satu faktor yang paling berpengaruh dalam peningkatan mutu pendidikan adalah guru, karena guru berinteraksi secara langsung dengan peserta didik dalam kegiatan pembelajaran.

Salah satu peran guru adalah menyusun perangkat perencanaan pembelajaran, misalnya Rencana Pelaksanaan Pembelajaran (RPP). Setiap guru pada satuan pendidikan berkewajiban menyusun RPP secara lengkap dan sistematis agar tujuan pembelajaran tercapai. Uno (2009:3) mengemukakan bahwa perlunya perencanaan pembelajaran dimaksudkan agar dapat dicapai perbaikan pembelajaran. Untuk memaksimalkan kinerja guru tersebut perlu dilakukan upaya - upaya yang dapat memotivasi guru untuk menjadi lebih baik, salah satunya adalah dengan memaksimalkan peran serta kepala sekolah dalam upaya memberikan bantuan, perbaikan ataupun pembinaan terhadap kinerja guru dalam proses pembelajaran di kelas melalui supervisi.

Pengawasan yang dilakukan oleh kepala sekolah pada intinya yaitu melakukan pembinaan, bimbingan untuk memecahkan masalah 
pendidikan termasuk masalah yang dihadapi guru secara bersamaan dan bukan mencari kesalahan guru. Arikunto (2004:5) mengemukakan bahwa, kegiatan pokok supervisi adalah melakukan pembinaan kepada sekolah pada umumnya dan guru pada khususnya agar kualitas pembelajarannya meningkat.

Dampak dari meningkatnya kualitas pembelajaran, tentu dapat pula meningkatkan prestasi belajar siswa, dan itu berarti meningkatlah kualitas lulusan di sekolah tersebut, karena hasil ujian yang baik akan menjadi salah satu indikator kualitas guru. Sementara hasil supervisi sebelumnya yang dilakukan setiap semester menunjukkan tidak ada peningkatan dalam perangkat pembelajaran terutama dalam menyusun RPP.

Dengan menyadari gejala-gejala atau kenyataan tersebut diatas, maka diadakan penelitian dengan judul Peningkatan Kemampuan Guru Bahasa Dalam Menyusun RPP dengan Menggunakan Metode Supervisi Akademik di Smp Negeri 3 Matan Hilir Selatan.

Berdasarkan latar belakang yang telah dipaparkan diatas, rumusan masalah dalam penelitian ini yaitu: (1) Bagaimana proses pembuatan RPP oleh guru bahasa dis SMP Negeri 3 Matan Hilir Selatan?. (2) Apakah penggunaan metode supervisi akademik dapat meningkatkan kemampuan menyusun RPP guru bahasa di SMP Negeri 3 Matan Hilir Selatan?.

Sesuai dengan permasalahan di atas, penelitian ini bertujuan untuk: (1) Untuk mendeskripsikan proses pembuatan RPP oleh guru bahasa dis SMP Negeri 3 Matan Hilir Selatan. (2) Untuk mengetahui peningkatan kemampuan guru bahasa dalam menyusun RPP dengan menggunakan metode supervisi akademik di SMP Negeri 3 Matan Hilir Selatan.

Adapun maksud peneliti mengadakan penelitian ini diharapkan dapat berguna bagi kepala sekolah untuk meningkatkan kinerja kepala sekolah dalam memberikan layanan supervisi pembelajaran terhadap guru dan mengembangkan kreatifitas penulisan karya ilmiah, bagi guru dapat meningkatkan kemampuan guru dalam menyusun RPP dan meningkatkan kualitas pembelajaran dalam kurikulum K13, serta manfaatnya bagi sekolah sebagai contoh pembuatan RPP untuk guru mata pelajaran lainnya dan untuk menciptakan inovasi peningkatan kemampuan guru bahasa dalam menyusun RPP

Dalam proses administrasi pendidikan, kegiatan supervisi akademik tidak dapat dipisahkan. Menurut Nawawi (1997:99) menyatakan bahwa "supervisi merupakan suatu kegiatan pengawasan yang dilakukan oleh seorang pejabat terhadap bawahannya untuk melakukan tugas - tugas dan kewajibannya dengan baik sesuai pertelaan tugas yang digariskan". Pengertian ini lebih menekankan kepada pengawasan murni dalam arti kontrol kegiatan dari seorang atasan terhadap bawahannya agar melaksanakan kewajiban dengan sebaikbaiknya.

Untuk mengembangkan efektivitas kinerja personalia sekolah yang berhubungan dengan tugas - tugas utama pendidikan diperlukan kegiatan supervisi, hal ini sesuai dengan pendapat Mulyasa (2003: 155) yang menyatakan bahwa "Supervisi sebagai suatu usaha memberikan layanan kepada guru-guru baik secara individual maupun secara kelompok dalam usaha memperbaiki pengajaran"

Dalam Permendiknas No 13 Tahun 2007 disebutkan bahwa kompetensi supervisi kepala sekolah adalah ; a) Merencanakan program supervisi akademik dalam rangka peningkatan profesionalisme guru, b) Melaksanakan supervisi akademik terhadap guru dengan menggunakan pendekatan dan teknik supervisi yang tepat dan c) Menindaklanjuti hasil supervisi akademik terhadap guru dalam rangka peningkatan profesionalisme guru.

Dari uraian diatas dapat disimpulkan bahwa tujuan jangka panjang dari supervisi adalah perbaikan pengajaran yang dilakukan oleh guru. Guru merupakan faktor penting dalam proses pelaksanaan pembelajaran, sehingga pengawasan terhadap proses pembelajaran yang dilakukan oleh guru sangat penting agar kompetensi siswa dapat tercapai.

Supervisi akademik diselenggarakan dengan maksud untuk memonitor kegatan belajar mengajar. Diawali dengan mengidentifikasi kelemahan - kelemahan pembelajaran untuk diperbaiki, apa yang menjadi penyebabnya dan mengapa guru tidak berhasil melaksanakan tugas dengan baik, kemudian diadakan tidak lanjut berupa perbaikan dalam bentuk pembinaan oleh kepala sekolah. 
Terdapat tiga tujuan dan fungsi supervisi akademik menurut Badan BSDMP (2011: 6), yaitu :"(1) Membantu guru mengembangkan kompentensinya. (2) Mengembangkan kurikulum, dan (3) Mengembangkan kelompok kerja guru, dan membimbing penelitian tindakan sekolah (PTS). Hasil supervisi akademik tersebut berfungsi sebagai sumber informasi bagi pengembangan profesionalisme guru.

Menurut Idochi Anwar (2003: 55), guru yang profesional adalah guru yang melakukan tugas mengajarnya dengan baik. Dibutuhkan keterampilanketerampilan antara lain: (1) Keterampilan membuka dan menutup pelajaran, (2) Ketermpilan menjelaskan, (3) Keterampilan bertanya, (4) Keterampilan memberi penguatan, (5) Keterampilan menggunakan media pembelajaran, (6)Keterampilan membimbing diskusi kelompok kecil, (7) Keterampilan mengelola kelas, (8) Keterampilan mengadakan variasi, (9) Keterampilan mengajar perorangan dan kelompok kecil.

Direktorat manajemen Depdiknas (2010: 336-337) menjelaskan bahwa tugas profesional guru meliputi tugas merencanakan, melaksanakan, dan menilai pembelajaran. Dengan demikian dapat disimpulkan bahwa indikator keberhasilan kepala sekolah dalam supervisi akademik adalah jika dalam perencanaan pembelajaran guru mampu memahami tujuan pembelajaran, melakukan analisis pembelajaran, mengenal perilaku siswa, mengidentifikasi karakteristik siswa, merumuskan tujuan pembelajaran.

Setiap guru pada satuan pendidikan berkewajiban menyusun RPP secara lengkap dan sistematis agar pembelajaran berlangsung secara interaktif, inspratif, menyenangkan, menantang, memotivasi peserta didik untuk berpartisipasi aktif, serta memberikan ruang yang cukup bagi prakarsa, kreativitas, dan kemandirian sesuai dengan bakat, minat, dan pekembangan fisik serta psikologis peserta didik. Guru merancang RPP untuk setiap pertemuan yang disesuaikan dengan penjadwalan di satuan pendidikan.

Menurut Sahlan (2017: 53) Rencana Pelaksanaan Pembelajaran (RPP) adalah rancangan pembelajaran mata pelajaran perunit yang akan diterapkan guru dalam pembelajaran di kelas. Menurut Peraturan Menteri Pendidikan Nasional No. 41 tahun 2007, RPP dijabarkan dari silabus untuk mengarahkan kegiatan belajar peserta didik dalam upaya mencapai KD.

Ciri-ciri Rencana Pelaksanaan Pembelajaran (RPP) yang baik adalah memuat aktivitas proses belajar mengajar yang akan dilaksanakan oleh guru yang akan menjadi pengalaman belajar bagi siswa. Langkah - langkah pembelajaran disusun secara sistematis agar tujuan pembelajaran dapat dicapai dan langkah-langkah pembelajaran disusun serinci mungkin, sehingga mudah dipahami dan tidak menimbulkan penafsiran ganda jika dipakai oleh guru lain.

\section{METODE PENELITIAN}

Peneliti menggunakan pendekatan kualitatif (metode penelitian kualitatif) yang bersifat deskriptif. Salah satu ciri penelitian kualitatif adalah bercorak deskriptif yaitu dengan menggunakan data deskriptif yang banyak dituangkan dalam bentuk laporan dan uraian berupa kata-kata, gambar dan bukan angka-angka. (Sugiyono, 2013:393)

Bentuk penelitian ini merupakan Penelitian Tindakan Sekolah (PTS). Terkait dengan hal tersebut maka penelitian ini terdiri dari dua siklus dan dilaksanakan dengan menggunakan metode supervisi akademik yang bertujuan untuk meningkatkan kemampuan penyusunan RPP pada mata pelajaran bahasa Indonesia dan bahasa inggris. (Suwandi, 2011:11)

Mengingat penelitian yang dilakukan adalah dengan bentuk Penelitian Tindakan Sekolah (PTS), maka penelitian ini sifatnya adalah kolaboratif, Untuk itu penelitian ini berkolaborasi antara guru SMP Negeri 3 Matan Hilir Selatan Kabupaten Ketapang. Penelitian ini dilaksanakan di SMP Negeri 3 Matan Hilir Selatan Dalam penelitian ini kepala sekolah berkolaborasi dengan guru bahasa Indonesia dan guru bahasa inggris.

Penelitian ini menggunakan prosedur Penelitian Tindakan Sekolah yang terdiri dari perencanaan, pelaksanaan, observasi, dan refleksi yang dilaksankan di SMP Negeri 3 Matan Hilir Selatan dengan pelaksanaan dua siklus, masingmasing siklus terdiri dari satu kali pertemuan dan dilaksanakan dengan berkolaborasi antara peneliti dengan guru.

Terdapat dua instrument dalam penelitian ini, yaitu lembar observasi kepala sekolah dan lembar observasi guru, yang mana lembar observasi kepala 
sekolah berupa lembar pengamatan yang berkaitan dengan aktivitas kepala sekolah selama proses supervisi akademik apakah sudah sesuai dengan Rencana Pelaksanaan Pembelajaran (RPP) yang diharapkan, lembar ini diisi oleh waka kurikulum dan lembar obsrvasi guru yang harus diisi kepala sekolah saat melakukan supervisi akdemik pada guru bahasa di siklus 1 dan 2 dilaksanakan.

Penelitian ini dilaksanakan dalam dua siklus, yang mana setiap siklusnya akan melalui 4 tahapan, yaitu, (1) tahap perencanaan, (2) tahap pelaksanaan, dan (3) tahap observasi, dan (4) tahap refleksi. Tahap-tahap tersebut dapat dirinci seperti sebagai berikut.

Pada tahap perncanaan peran peneliti menyiapkan segala sesuatu yang berkenaan dengan rencana tindakan yang akan dilakukan berkaitan dengan supervisi akademik yaitu menugaskan guru bahasa menyususn RPP dan membuat lembar observasi.

Pada tahap kedua, yaitu tahap pelaksanaan, peran peneliti adalah untuk mengimplementasikan proses tindakan sesuai rencana yang sudah disusun, melaksanakan rencana yang sudah disepakati dan sebagai pelaksanaan supervisi akademik terhadap guru bahasa dalam menyusun RPP.

Pada tahap observasi/pengamatan ini peneliti meminta waka kuriulum untuk melakukannya. Dari hasil observasi maka dapat dilihat berhasil atau tidaknya penerapan supervisi akademik terhadap guru bahasa dalam menyusun RPP di SMP Negeri 3 Matan Hilir Selatan.

Pada tahap terakhir, yaitu tahap refleksi, Hasil observasi didiskusikan supervisor dan guru bahasa tentang kekurangan dan masalah yang dihadapi ketika proses pelaksanaan siklus I dan siklus seterusnya.

Teknik pengumpulan data dalam penelitian ini adalah teknik observasi langsung dan pengukuran. Teknik observasi adalah pengamatan dan pencatatan secara sistematik terhadap gejala yang tampak pada objek penelitian. Teknik ini merupakan cara untuk mengumpulkan data yang dilakukan melalui pengamatan dan observasi peningkatan menyusuan RPP, serta yang menjadi indikator untuk mengukur keberhasilan dalam penelitian ini adalah Rata-rata penyusunan RPP siklus sesudahnya lebih baik dari siklus sebelumnya.

\section{HASIL DAN PEMBAHASAN PENELITIAN}

Data penelitian yang diperoleh adalah hasil observasi yang dilaksanakan pada saat supervisi akademik menggunakan lembar observasi yang telah disiapkan, yaitu lembar observasi terhadap kepala sekolah dan lembar observasi terhadap guru bahasa dalam penyusunan RPP. Data yang diperoleh selanjutnya dievaluasi.

Dalam perencanaan pembelajaran siklus I ini, peneliti sekaligus sebagai kepala sekolah dalam kegiatan pelaksanaan melakukan supervisi akademik dalam penyusunan RPP menyiapkan lembar pengamatan/observasi supervisi mengenai penyusunan RPP. Adapun guru yang terlibat adalah guru bahasa yaitu bahasa Indonesia dan bahasa inggris di SMP Negeri 3 Matan Hilir Selatan.

Pelaksanaan Supervisi akademik pada siklus I dilaksanakan pada tanggal 20 September 2019. Guru menyajikan RPP kurikulum K13 mata pelajaran bahasa Indonesia dan pelajaran bahasa inggris di SMP Negeri 3 Matan Hilir Selatan. Adapun tahap-tahap pelaksanaan supervisi akademik yaitu: kegiatan awal pembelajaran, kegiatan inti pembelajaran dan kegiatan akhir pembelajaran.

kegiatan awal pelaksanaan komponenkomponen RPP yang telah disupervisi secara akademik didapat kan hasil yang kurang maksimal dalam penyusuan kegiatan awal pembelajaran dalam RPP yang disusun oleh guru bahasa Indonesia dan guru bahasa inggris. Kendala yang didapat pada saat ini adalah kurang sesuainya dalam penentuan tujuan pelajaran yang terkait dengan indikator pencapaian kompetensi guru hanya menjabarkan secara gambaran umum saja.

Pada proses pembelajaran inti terdapat tahapan - tahapan sintak metode pembelajaran yang dipilih berdasarkan pendekatan saintifik yaitu mencakup perumusan masalah, merencanakan, menganalisis masalah, menggumpulkan data, mengkomunikasikan dan menarik kesimpulan. Kendala yang didapat pada saat supervisi kegiatan inti dalam penyusunan RPP yaitu pemilihan model dan metode pembelajaran yang kurang sesuai dengan pendekatan saintifik dalam kurikulum K13

Pada kegiatan akhir, guru menyimpulkan materi pembelajaran yang sudah diajarkan dengan melibatkan siswa secara bersama-sama. Kendala yang didapat pada tahapan ini adalah kurang efektif nya penyampaian kesimpulan dan guru tidak 
mengadakan kegiatan tes serta remedial dan pengayaan kepada siswa pada tahap akhir ini, sehingga tidak ada penilaian yang didapat.

Pada siklus I, secara garis besar kegiatan belajar mengajar dengan merapkan metode pengajaran terarah sudah dilaksanakan dengan baik, walaupun peran guru masih cukup dominan untuk memberikan penjelasan dan arahan karena model tersebut masih dirasakan baru oleh siswa.

Berikutnya adalah rekapitulasi hasil penyusunan RPP guru pada siklus I, guru bahasa Indonesia I (60\%), guru bahasa Indonesia II (45\%), guru bahasa inggris I (50\%) dan guru bahasa inggris II (40\%). Hal ini disebabkan karena kurangnya pemahaman guru dalam menentukan tujuan pembelajaran, penggunaan media pembelajaran, penggunaan metode pembelajaran yang masih mengacu kepada kurikulum KTSP, serta media pembelajaran hanya berbasis tradisional.

Tahap akhir dari siklus I ini adalah tahapan Refleksi yang dimana kepala sekolah menelaah semua permasalahan yang ada didalam proses supervisi akademik yang dituangkan dalam lembar observasi. pelaksanaan supervisi akademik pada siklus I belum terlaksana dengan baik seperti apa yang telah direncanakan sebelumnya. Hal ini disebabkan karena dari pelaksanaan supervisi akademik dalam menyusun RPP belum optimal, sehingga perlu melaksanakan kegiatan supervisi siklus II.

Tabel 1. Hasil supervisi Akademik pada guru bahasa Siklus I

\begin{tabular}{cccc}
\hline No & \multicolumn{1}{c}{ Guru mapel } & Hasil penyusunan RPP & Keterangan \\
\hline 1. & Guru bahasa Indonesia I & $60,00 \%$ & Cukup \\
\hline 2. & Guru bahasa Indonesia II & $45,00 \%$ & Kurang \\
\hline 3. & Guru bahasa inggris I & $50,00 \%$ & Kurang \\
\hline 4. & Guru bahasa inggris II & $40,00 \%$ & Kurang \\
\hline
\end{tabular}

Dari tabel di atas diperoleh hasil setiap guru bahasa dalam menyusun RPP sebagian besar masih kurang. Adapun hambatan/kekurangan-kekurangan yang ada dalam pelaksanaan supervisi akademik siklus I antara lain : (1) Kurangnya pemahaman guru dalam menentukan tujuan pembelajaran, penggunaan media pembelajaran, kurang tepatnya penggunaan metode pembelajaran belum biasa dikategorikan dalam pembelajaran saintifik masih mengacu kepada kurikulum KTSP. Dan (2) Keterbatasan guru dalam mengguasai ilmu teknologi sehingga media pembelajaran hanya berbasis tradisional tidak bias menyajikan media pembelajaran yang menarik dan kreatif serta inovatif.

Dari hasil refleksi dan diskusi, diperoleh kesepakatan bahwa pelaksanaan supervisi akademik pada siklus I belum terlaksana dengan baik seperti apa yang telah direncanakan sebelumnya. Hal ini disebabkan karena dari pelaksanaan supervisi akademik dalam menyusun RPP belum optimal, sehingga perlu melaksanakan kegiatan supervisi siklus II. Namun demikian hal positif/kelebihan dari pembelajaran siklus I ini adalah bahwa secara umum proses penyusunaan dan urutan pembuatan RPP sudah terlaksanan dengan baik walaupun belum optimal.

\section{Siklus II}

Pada siklus II, peneliti sekaligus sebagai kepala sekolah telah membuat perencanaan yang berbeda dari siklus sebelumnya antara lain menugaskan guru bahasa Indonesia dan guru bahasa inggris menyusun RPP dengan materi yang baru (berupa kelanjutan dari materi sebelumnya), menyiapkan lembar pengamatan/observasi supervisi mengenai penyusunan RPP.

Pelaksanaan Siklus II dilaksankan pada tanggal 2 Oktober 2019. Pada pelaksanaan ini peneliti melaksanakan supervisi akademik untuk memperbaiki kekurangan penyusunan RPP. Guru menyajikan RPP kurikulum K13 mata pelajaran bahasa Indonesia dan pelajaran bahasa inggris di SMP Negeri 3 Matan Hilir Selatan. Adapun tahap-tahap pelaksanaan supervisi akademik pada siklus ke II ini yaitu: kegiatan awal pembelajaran, kegiatan inti pembelajaran dan kegiatan akhir pembelajaran. 
Pada kegiatan awal pelaksanaan supervisi dilakukan penyususnan komponen -komponen RPP yang mencantumkan kompetensi inti, kompetensi dasar dan membuat tujuan pembelajaran yang sesuai dengan indikator pencapaian kompetensi (IPK), menampilkan materi pelajaran, memilih model dan metode pembelajaran yang tepat. RPP yang dibuat guru bahasa Indonesia dan guru bahasa inggris pada siklus II terdapat perbedaan serta peningkatan. Hal ini dibuktikan pada hasil supervisi yang telah dilakukan oleh kepala sekolah terhadap guru bahasa yang dimana pada tahapan penyusuanan kompetensi inti, kompetensi dasar dan membuat tujuan pembelajaran sudah mencapai target yang diinginkan, serta dalam penggunaan media pembelajaran pun guru bahasa sudah bisa menggunakan media pembelajaran yang kreatif dan inovatif yang sesuai dengan materi pelajaran yang diajar.

Aspek yang diobservasi Pada kegiatan inti yaitu tahap-tahapan kegiatan pembelajaran berdasarkan sintak metode dan model pembelajaran yang telah dipilih. Egiatan tersebut mencakup kegiatan pendahuluan, kegiatan inti dan penutup. Hasil yang didapat pada tahapan siklus II yaitu terjadi peningkatan dalam penggunaan model pembelajaran yang dimana guru bahas sudah menerapkan pendekatan pembelajaran saintifik yang terkandung dalam kurikulum K13. Hal ini dibuktikan dalam penyusunan RPP oleh guru bahasa menerapkan model problem based learning dan metode discovery learning. Dalam proses pembelajaran peranan guru pada pembelajaran hanya sebagai fasilitator saja sehingga siswa berperan aktif dalam proses pembelajaran.
Pada kegiatan akhir, guru menyimpulkan materi pembelajaran yang sudah diajarkan dengan melibatkan siswa secara bersama-sama. Hasil yang didapat pada siklus II terjadi peningkatan yang mana guru menyimpulkan materi pembelajaran bersama- sama siswa, mengadakan kegiatan tes serta remedial dan pengayaan kepada siswa pada tahap akhir, sehingga didapat hasil nilai dari kognitif, afektif dan pisikomotorik siswa.

Pada tahap observasi, supervisi akademik pada siklus II berlangsung dengan menggunakan lembar observasi yang telah disiapkan, yaitu lembar observasi terhadap kepala sekolah dan lembar observasi terhadap guru bahasa dalam penyusunan RPP. Data yang diperoleh selanjutnya dievaluasi. Hasil observasi supervisi penyusunan RPP terhadap guru bahas pada siklus II yaitu guru bahasa Indonesia I (80\%), guru bahasa inonesia II $(85 \%)$, guru bahasa inggris I (90\%) dan guru bahasa inggris II (75\%).

Pada tahap refleksi, peneliti bersama observer melakukan evaluasi terhadap hasil observasi, terhadap guru bahasa. Adapun peningkatan penyususnan RPP yang ada dalam pelaksanaan supervisi akademik siklus II adalah tercapainya indikator pencapaian kompetensi melalui tujuan pembelajaran, apabila rencana pembelajaran disusun secara baik akan menjadikan tujuan pembelajaran dapat dicapai secara efektif dan efisien.

Berikutnya adalah rekapitulasi hasil supervisi akademik guru bahasa siklus II tabel berikut:

Tabel 2. Hasil Supervisi Akademik pada Guru Bahasa Siklus II

\begin{tabular}{clcc}
\hline No & \multicolumn{1}{c}{ Guru mapel } & Hasil penyusunan RPP & Keterangan \\
\hline 1. & Guru bahasa Indonesia I & $80,00 \%$ & Baik \\
\hline 2. & Guru bahasa Indonesia II & $85,00 \%$ & Sangat baik \\
\hline 3. & Guru bahasa inggris I & $90,00 \%$ & Sangat baik \\
\hline 4. & Guru bahasa inggris II & $75,00 \%$ & Baik \\
\hline
\end{tabular}


Dari tabel di atas diperoleh hasil setiap guru bahasa dapat menyusun RPP dengan baik. Melihat dari hasil yang diajabarkan dalam kegiatan penelitian tindakan sekolah ini, disimpulkan bahwa supervisi akademik yang dilakukan oleh kepala sekolah terhadap empat orang guru bahasa yaitu 2 orang guru bahasa Indonesia dan 2 orang guru bahasa inggris telah berhasil meningkatkan kemampuan dalam penyusunan RPP. Hal ini dimungkin kan karena adanya kerja sama yang baik antara kepala sekolah sebagai supervisor dengan para guru tersebut, yang didukung oleh adanya motivasi dan bimbingan dari kepala sekolah sehingga para guru memiliki antusiasme yang besar untuk dapat meningkatkan kemampuan mereka masing-masing dalam penyusunan RPP yang efektif.

\section{Pembahasan}

Melalui hasil penelitian ini menunjukkan bahwa metode supervisi akademik memiliki dampak positif dalam meningkatkan kemampuan guru bahasa menyusun RPP. Hal ini dapat dilihat dari semakin mantapnya hasil penilaian observasi guru dari siklus I, dan II, yaitu masing-masing siklus I pada guru bahasa Indonesia I (60\%), guru bahasa Indonesia II (45\%), guru bahasa inggris I $(50 \%)$ dan guru bahasa inggris II (40\%) dan pada siklus II terdapat peningkatan pada guru bahasa Indonesia I (80\%), guru bahasa inonesia II $(85 \%)$, guru bahasa inggris I $(90 \%)$ dan guru bahasa inggris II (75\%).

Pada siklus I, secara garis besar kegiatan belajar mengajar dengan merapkan metode pengajaran terarah sudah dilaksanakan dengan baik, walaupun peran guru masih cukup dominan untuk memberikan penjelasan dan arahan karena model tersebut masih dirasakan baru oleh siswa.

pelaksanaan supervisi pada siklus II dilakukan penyususnan komponen -komponen RPP yang mencantumkan kompetensi inti, kompetensi dasar dan membuat tujuan pembelajaran yang sesuai dengan indikator pencapaian kompetensi (IPK), menampilkan materi pelajaran, memilih model dan metode pembelajaran yang tepat. RPP yang dibuat guru bahasa Indonesia dan guru bahasa inggris pada siklus II terdapat perbedaan serta peningkatan. Hal ini dibuktikan pada hasil supervisi yang telah dilakukan oleh kepala sekolah terhadap guru bahasa yang dimana pada tahapan penyusuanan kompetensi inti, kompetensi dasar dan membuat tujuan pembelajaran sudah mencapai target yang diinginkan, serta dalam penggunaan media pembelajaran pun guru bahasa sudah bisa menggunakan media pembelajaran yang kreatif dan inovatif yang sesuai dengan materi pelajaran yang diajar.

\section{SIMPULAN DAN SARAN Simpulan}

Dari hasil supervise akademik selama dua siklus, dan berdasarkan seluruh pembahasan serta analisis yang telah dilakukan dapat disimpulkan sebagai berikut: (1) Dengan menerapkan metode supervisi akademik dalam penyusunan RPP pada guru bahasa terdapat hasil yang berbeda pada siklus I dan siklus II yaitu pada siklus I didapat hasil yang kurang maksimal dalam pembuatan dan penyusuanan komponen-komponen RPP sedangkan pada siklus II didapat hasil yang maksimal hal ini dibuktikan pada lembar observasi dan hasil persentasi siklus II. (2) Metode supervisi akademik dapat meningkatkan kemampuan penyusunan RPP pada guru bahasa hal ini didasarkan pada hasil siklus I dan siklus II. Pada siklus I tidak terjadi peningkatan yang maksimal sedangkan pada siklus II didapat hasil peningkatan yang baik, hal ini terjadi karena adanya bimbingan dari supervisor dalam hal ini adalah kepala sekolah melalui kegiatan supervisi akademik.

\section{Saran}

Dari hasil penelitian yang diperoleh dari uraian sebelumnya agar kegiatan supervisi akademik lebih efektif dan lebih memberikan hasil yang optimal, maka disampaikan saran 
sebagai berikut: (1) Kegiatan supervisi akademik, sebaiknya tidak hanya dilaksanakan satu atau dua kali saja dalam satu semester, karena RPP merupakan panduan guru dalam mengajar. (2) Kepala sekolah sebaiknya memberikan tanda tangan setiap minggu sehingga guru membuat RPP baru setiap akan mengajarkan materi. (3) Kepala sekolah menyusun jadwal terstruktur untuk melakukan pembinaan tentang RPP. (4) Selalu melakukan inovasi dalam pembelajaran dengan terus mencoba hal-hal baru sehingga siswa tidak merasa bosan.

\section{DAFTAR PUSTAKA}

Arikunto, Suharsimi. (2004). Dasar-Dasar Supervisi. Rineka Cipta : Jakarta

Badan BSDMP. (2011). Suplemen Materi Pelatihan Penguatan Kemampuan Kepala Sekolah. Direktorat Tenaga Kependidikan Ditjen Peningkatan Mutu Tenaga Pendidik \& Tenaga Kependidikan. Jakarta.

Depdiknas. (2010). Modul pelatihan penguatan kemampuan pengawas sekolah supervisi akademik. Direktorat Tenaga
Kependidikan Ditjen Peningkatan Mutu Tenaga Pendidik \& Tenaga Kependidikan .Yogyakarta.

Idochi Anwar . (2003). Administrasi Pendidikan dan Manajemen Biaya Pendidikan. Alfabeta : Bandung.

Mulyasa. (2003). Menjadi Kepala Sekolah Profesional. Remaja Rosda Karya : Bandung.

Nawawi Hadari. (1997). Administrasi Pendidikan. PT. Gunung Agung : Jakarta.

Permendiknas No 13. (2007). Tentang Supervisi Akademik Materi Pelatihan Penguatan Kemampuan Kepala sekolah.

Sahlan Asmaun. (2017). Desain Pembelajaran Berbasis Pendidikan Karakter. AR- Ruzz Media: Yogyakarta .

Sugiyono. (2013). Metode penelitian pendidikan pendekatan kuantitatif dan kualitatif dan $R \& D$. ALFA BETA: Bandung.

Suwandi, sarwiji. (2011). Penelitian Tindakan Kelas (PTK dan Penulisan Karya Ilmiah). Yuma Pustaka: Surakarta.

Uno, Hamzah. (2009) . Model Pembelajaran, Menciptakan Proses Belajar Mengajar yang Kreatif. Bumi Aksara: Jakarta. 